Nevada

Environmental

Restoration

Project

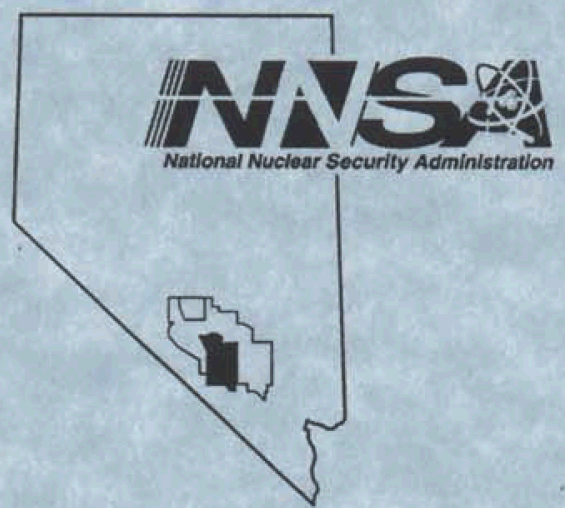

Corrective Action Plan for

Corrective Action Unit 335: Area 6 Injection Well and Drain Pit

Nevada Test Site, Nevada

Controlled Copy No.

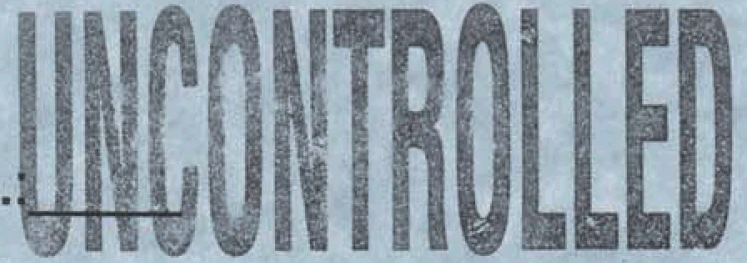

Revision: 1

October 2002

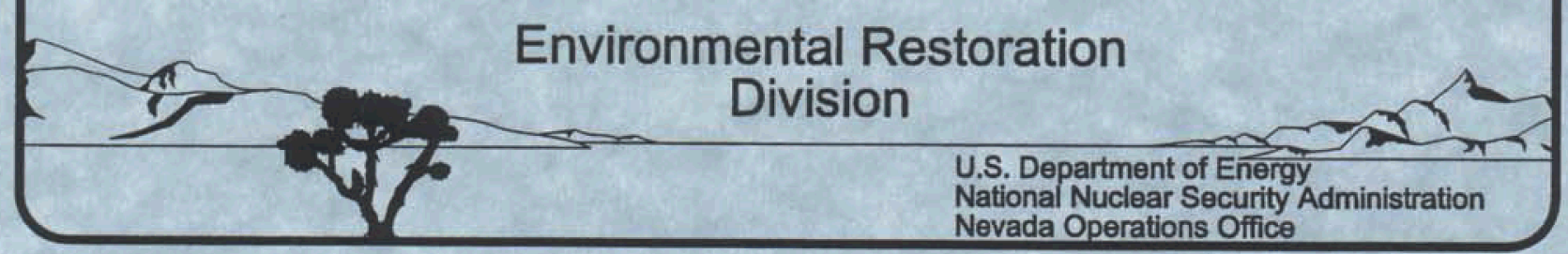




\section{DISCLAIMER STATEMENT}

Reference herein to any specific commercial product, process, or service by trade name, trademark, manufacturer, or otherwise, does not necessarily constitute or imply its endorsement, recommendation, or favoring by the U.S. Government or any agency thereof or its contractors or subcontractors.

\section{AVAILABILITY STATEMENT}

Available for sale to the public from-

U.S. Department of Commerce

National Technical Information Service

5285 Port Royal Road

Springfield, VA 22161-0002

Telephone: 800.553 .6847

Fax: 703.605 .6900

E-mail: orders@ntis.fedworld.gov

Online ordering: http://www.ntis.gov/ordering.htm

Available electronically at http://www.doe.gov/bridge

Available for a processing fee to U.S. Department of Energy and its contractors, in paper, from-

U.S. Department of Energy

Office of Scientific and Technical Information

P.O. Box 62

Oak Ridge, TN 37831-0062

Telephone: 865.576 .8401

Fax: 865.576.5728

E-mail: reports@adonis.osti.gov 


\title{
CORRECTIVE ACTION PLAN FOR CORRECTIVE ACTION UNIT 335: AREA 6 INJECTION WELL AND DRAIN PIT NEVADA TEST SITE, NEVADA
}

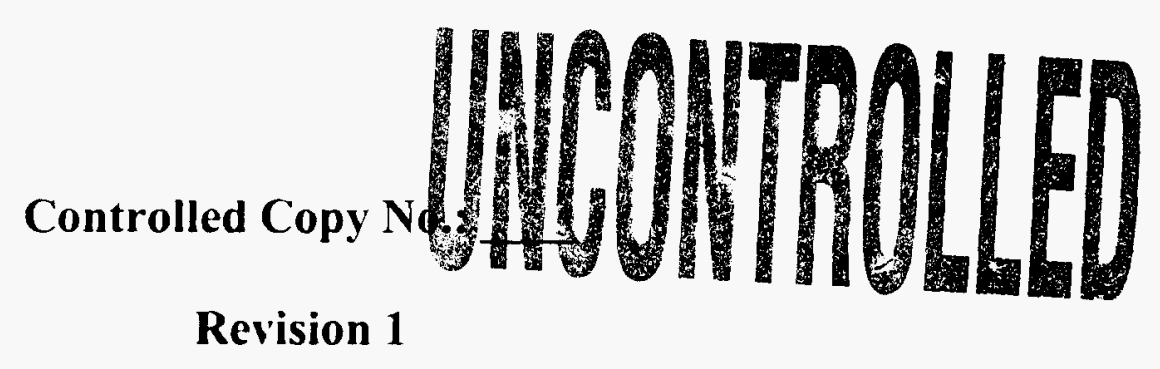

October 2002

\begin{abstract}
Prepared for
U.S. Department of Energy

National Nuclear Security Administration Nevada Operations Office Under Contract No. DE-AC08-96NV11718
\end{abstract}


THIS PAGE INTENTIONALLY LEFT BLANK 
DOE/NV--820-Rev 1

\section{CORRECTIVE ACTION PLAN FOR CORRECTIVE ACTION UNIT 335: AREA 6 INJECTION WELL AND DRAIN PIT NEVADA TEST SITE, NEVADA}

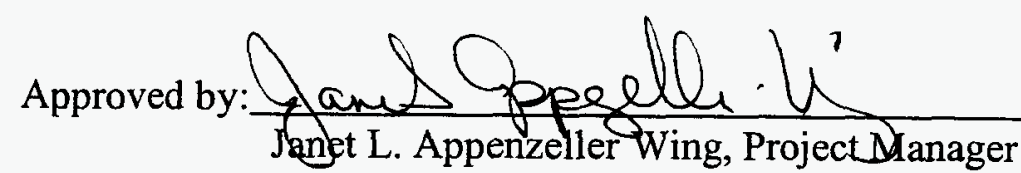
Industrial Sites Project

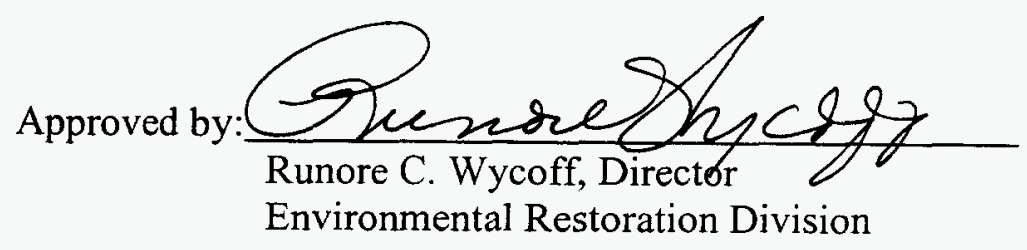

Date: $10 / 15 / 02$

Date: $10-15-02$ 
THIS PAGE INTENTIONALLY LEFT BLANK 


\section{TABLE OF CONTENTS}

ACRONYMS AND ABBREVIATIONS $\ldots \ldots \ldots \ldots \ldots \ldots \ldots \ldots \ldots \ldots$ vii

EXECUTIVE SUMMARY $\ldots \ldots \ldots \ldots \ldots \ldots \ldots \ldots \ldots \ldots \ldots \ldots \ldots \ldots \ldots \ldots$

1.0 INTRODUCTION $\ldots \ldots \ldots \ldots \ldots \ldots \ldots \ldots \ldots \ldots \ldots \ldots \ldots \ldots \ldots \ldots \ldots \ldots \ldots$

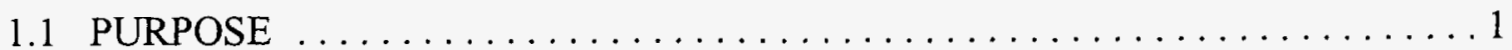

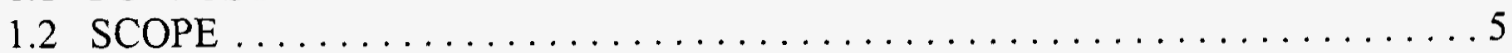

1.3 CORRECTIVE ACTION PLAN CONTENTS $\ldots \ldots \ldots \ldots \ldots \ldots \ldots \ldots$

2.0 DETAILED STATEMENT OF WORK $\ldots \ldots \ldots \ldots \ldots \ldots \ldots \ldots \ldots \ldots \ldots \ldots$

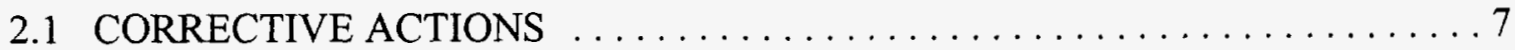

2.1.1 Preplanning and Site Preparation . . . . . . . . . . . . . 7

2.1.1.1 Site-Specific Health and Safety Plan/Job Hazard Analysis . . . .8

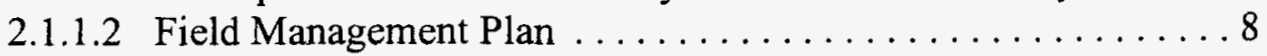

2.1.1.3 National Environmental Policy Act Documentation . . . . . . 8

2.1 .2 Closure Field Activities $\ldots \ldots \ldots \ldots \ldots \ldots \ldots \ldots \ldots \ldots$

2.1.2.1 CAS 06-20-01 Drums; Oil Waste; Spill Closure Activities . . . 8

2.1.2.2 CAS 06-20-02 20-inch Cased Hole Closure Activities . . . . . . 8

2.1.2.3 CAS 06-23-03 Drain Pit Closure Activities . . . . . . . . . . . .9

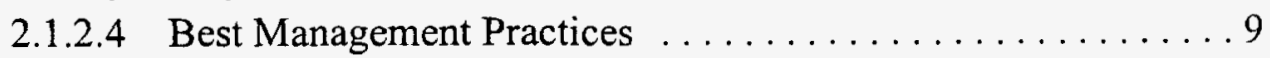

2.2 CONSTRUCTION QUALITY ASSURANCE/QUALITY CONTROL $\ldots \ldots \ldots 9$

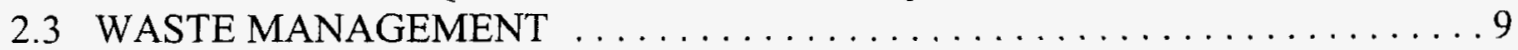

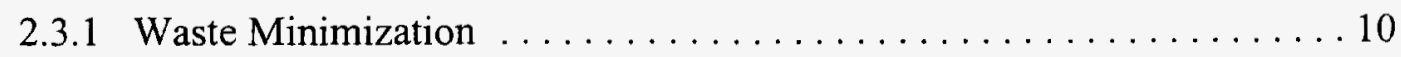

2.3.2 Site Control ............................ 10

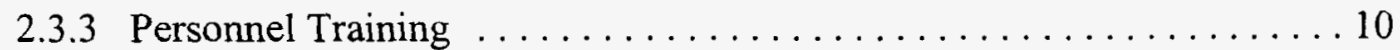

2.4 CONFIRMATION OF CORRECTIVE ACTIONS $\ldots \ldots \ldots \ldots \ldots \ldots \ldots \ldots$

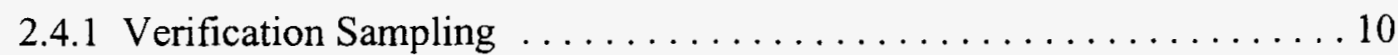

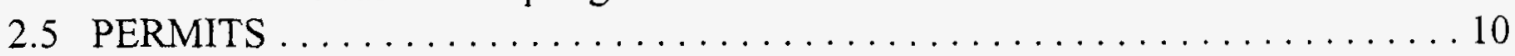

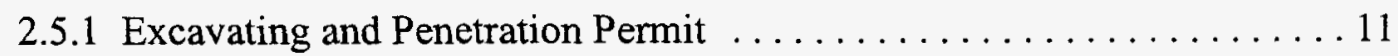

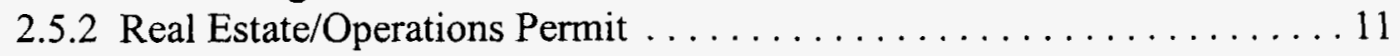

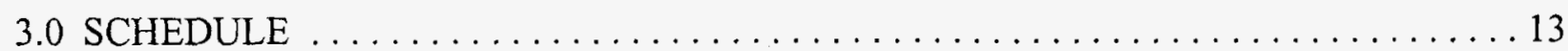

4.0 POST-CLOSURE MONITORING PLAN $\ldots \ldots \ldots \ldots \ldots \ldots \ldots \ldots \ldots \ldots \ldots$

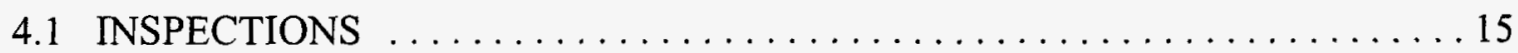

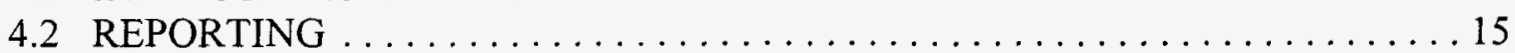

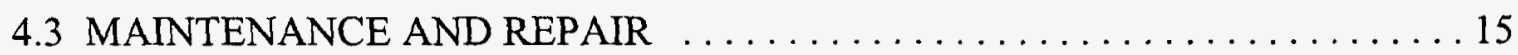

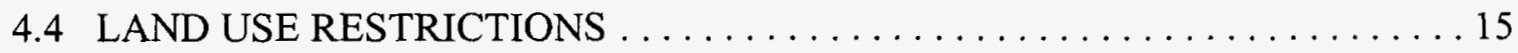

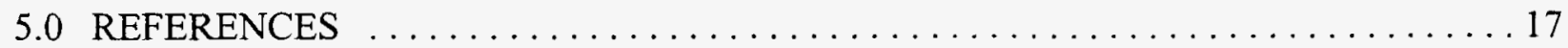




\section{TABLE OF CONTENTS (continued)}

\section{FIGURES}

FIGURE 1 - NEVADA TEST SITE AND CAU 335 LOCATION MAP ............. 2

FIGURE 2 - AREA 6 WELL 3 YARD LOCATION MAP $\ldots \ldots \ldots \ldots \ldots \ldots \ldots$

FIGURE 3 - CAS 06-20-01, CAS 06-20-02 AND CAS 06-23-03 SITE VICINITY MAP . . . . 4

\section{APPENDICES}

APPENDIX A-1 - ENGINEERING SPECIFICATIONS AND DRAWINGS

APPENDIX A-2 - SAMPLING AND ANALYSIS PLAN

APPENDIX A-3 - PROJECT ORGANIZATION

APPENDIX A-4 - NEVADA DIVISION OF ENVIRONMENTAL PROTECTION COMMENT RESPONSE

DISTRIBUTION LIST 


\section{ACRONYMS AND ABBREVIATIONS}

\begin{tabular}{|c|c|}
\hline $\mathrm{BN}$ & Bechtel Nevada \\
\hline $\mathrm{CADD}$ & Corrective Action Decision Document \\
\hline CAP & Corrective Action Plan \\
\hline CAS & Corrective Action Site \\
\hline $\mathrm{CAU}$ & Corrective Action Unit \\
\hline $\mathrm{COC}$ & Contaminant of concern \\
\hline $\mathrm{DOE} / \mathrm{NV}$ & U.S. Department of Energy, Nevada Operations Office \\
\hline FFACO & Federal Facility Agreement and Consent Order \\
\hline $\mathrm{ft}$ & foot(feet) \\
\hline gal & gallon(s) \\
\hline $\mathrm{km}$ & kilometer(s) \\
\hline $\mathrm{L}$ & liter(s) \\
\hline $\mathrm{m}$ & meter(s) \\
\hline $\mathrm{mi}$ & mile(s) \\
\hline NDEP & Nevada Division of Environmental Protection \\
\hline NEPA & National Environmental Policy Act \\
\hline NNSA/NV & $\begin{array}{l}\text { U.S. Department of Energy, National Nuclear Security Administration } \\
\text { Nevada Operations Office }\end{array}$ \\
\hline NTS & Nevada Test Site \\
\hline PPE & Personal Protective Equipment \\
\hline REOP & Real Estate/Operations Permit \\
\hline SSHASP & Site-Specific Health and Safety Plan \\
\hline ТPH & Total petroleum hydrocarbons \\
\hline
\end{tabular}


Date: October 2002

THIS PAGE INTENTIONALLY LEFT BLANK 


\section{EXECUTIVE SUMMARY}

The Area 6 Injection Well and Drain Pit is identified in the Federal Facility Agreement and Consent Order (1996) as Corrective Action Unit (CAU) 335. CAU 335 is located in Area 6 of the Nevada Test Site and consists of three Corrective Action Sites (CASs). This Corrective Action Plan provides the methodology for implementing the approved corrective action alternatives as listed in the Corrective Action Decision Document (U.S. Department of Energy, Nevada Operations Office [DOE/NV], 2001) for CAU 335. However, there is one modification to the selected alternative. Due to the large area that would require fencing, it is proposed that instead of fencing, an appropriate number of warning signs be used to delineate the use restriction area. CAU 335 includes the following three CASs:

- CAS 06-20-01, Drums; Oil Waste; Spill

- CAS 06-20-02, 20-inch Cased Hole

- CAS 06-23-03, Drain Pit

The corrective action investigation was performed in two phases. Phase 1 started in January 2001 and phase two started in May 2001. Investigation results indicated that the only contaminant of concern (COC) identified was total petroleum hydrocarbons (TPH) as dieselrange organics. No other COCs were detected above Preliminary Action Levels at any of the three CASs (DOE/NV, 2001). Concentrations of TPH exceeded the Nevada Division of Environmental Protection (NDEP) regulatory Action Level of 100 milligrams per kilogram (Nevada Administrative Code, 1996) at the three CASs. The three CASs that comprise CAU 335 will be closed as follows:

- $\quad$ CAS 06-20-01, Drums; Oil Waste; Spill; Closed with no further action required.

- CAS 06-20-02, 20-inch Cased Hole; Closed in Place with administrative controls, use restrictions and site postings which will be used to prevent intrusive activities at the site.

- CAS 06-23-03, Drain Pit; Closed in Place with administrative controls, which consist of use restrictions and site postings which will be used to prevent intrusive activities at the site. Grouting the plastic drain pipe protruding from the wall of the Drain Pit, and backfilling the Drain Pit with clean fill and grading to a natural slope to eliminate ponding.

CAS 06-20-01 consisted of four 208-Liter (55-gallon) drums containing material and debris pumped and removed from CAS 06-20-02. The drums were transported to the NTS Area 5 Hazardous Waste Accumulation Site in July 1991. Since the drums are no longer on-site, CAS 06-20-01 will be closed with no further action required. Any spills that may be associated with CAS 06-20-01 are addressed and considered part of CAS 06-20-02.

The proposed post-closure monitoring consists of annual (yearly) visual inspections of the signs for two years to verify that the signs are in place and readable, and that use restrictions are 
maintained. Any identified maintenance and repair requirements will be reported to NDEP and maintenance will be completed within 90 working days of discovery. Results of all inspections for a given year will be addressed in a single letter report submitted annually to the NDEP. If after two years, monitoring indicates that no maintenance is necessary, the U.S. Department of Energy, National Nuclear Security Administration Nevada Operations Office may propose to the NDEP a change in the post-closure monitoring frequency. 


\subsection{INTRODUCTION}

This Corrective Action Plan (CAP) has been prepared for Corrective Action Unit (CAU) 335, Area 6 Injection Well and Drain Pit, in accordance with the Federal Facility Agreement and Consent Order (FFACO) (1996). This CAP provides the methodology for implementing the approved corrective action alternative as listed in the Corrective Action Decision Document (CADD) (U.S. Department of Energy, Nevada Operations Office [DOE/NV], 2001). However, there is one modification to the selected alternative. Due to the large area that would require fencing, it is proposed that instead of fencing, an appropriate number of warning signs attached to tee posts be used to delineate the use restriction area.

CAU 335 is located in Area 6 of the Nevada Test Site (NTS) which is approximately 105 kilometers $(\mathrm{km})$ (65miles [mi]) northwest of Las Vegas, Nevada (Figure 1). CAU 335 is located in the Area 6 Well 3 Yard approximately $39 \mathrm{~km}(24 \mathrm{mi})$ north of Mercury, on the Mercury Highway and several hundred feet (ft) west along Road 6-06 (Figure 2). CAU 335 consists of the following three Corrective Action Sites (CASs):

- $\quad$ CAS 06-20-01, Drums; Oil Waste; Spill (Figure 3)

- CAS 06-20-02, 20-inch Cased Hole (Figure 3)

- CAS 06-23-03, Drain Pit (Figure 3)

The site history for CAU 335 is provided in the Corrective Action Investigation Plan (DOE/NV, 2000). Briefly, CAS 06-20-01, was used for storing material that was pumped out of CAS 06-20-02 and placed into four 208-liter (L) (55-gallon [gal]) drums. The drums were taken to the NTS Area 5 Hazardous Waste Accumulation Site in 1991. CAS 06-20-01 will be closed with no further action required. Any spills associated with CAS 06-20-01 are addressed and considered part of CAS 06-20-02. CAS 06-20-02 was used for disposal of used motor oil, wastewater, and debris for an undetermined amount of time. In 1991, the casing was emptied of its contents, excavated, and backfilled. CAS 06-23-03 was used as a depository for effluent waste from truck-washing activities from 1960 though 1991.

\subsection{PURPOSE}

The purpose of this CAP is to provide the strategy and methodology to close CAU 335 . The three CASs that comprise CAU 335 will be closed by implementing the approved closure alternatives as listed in the CADD (DOE/NV, 2001) and by following all state and federal regulations and the FFACO (1996). However, there is one modification to the selected alternative. Due to the large area that would need to be fenced, it is proposed that instead of fencing, an appropriate number of warning signs be used to delineate the use restriction area. 


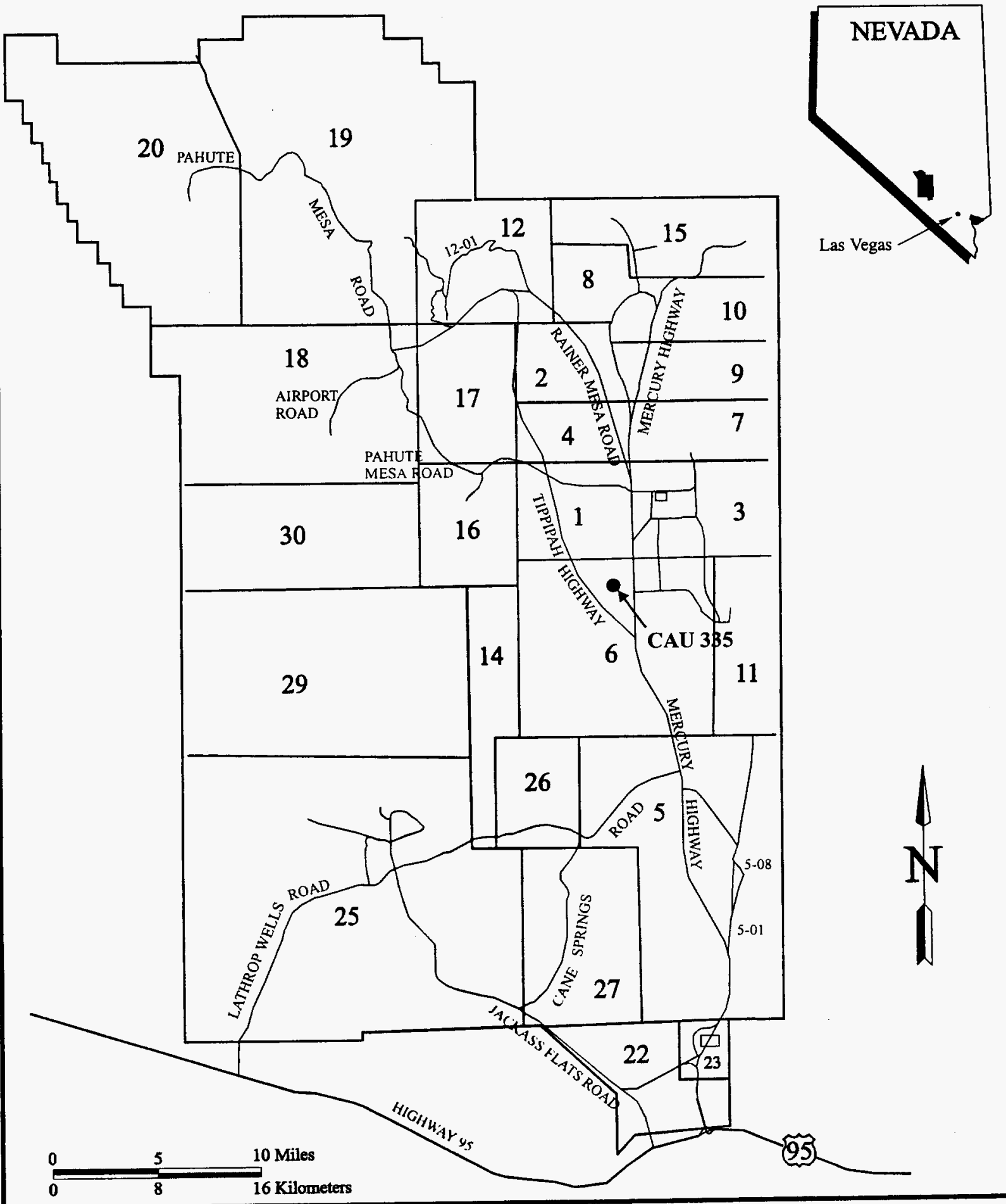

FIGURE 1

NEVADA TEST SITE AND CAU 335 LOCATION MAP 


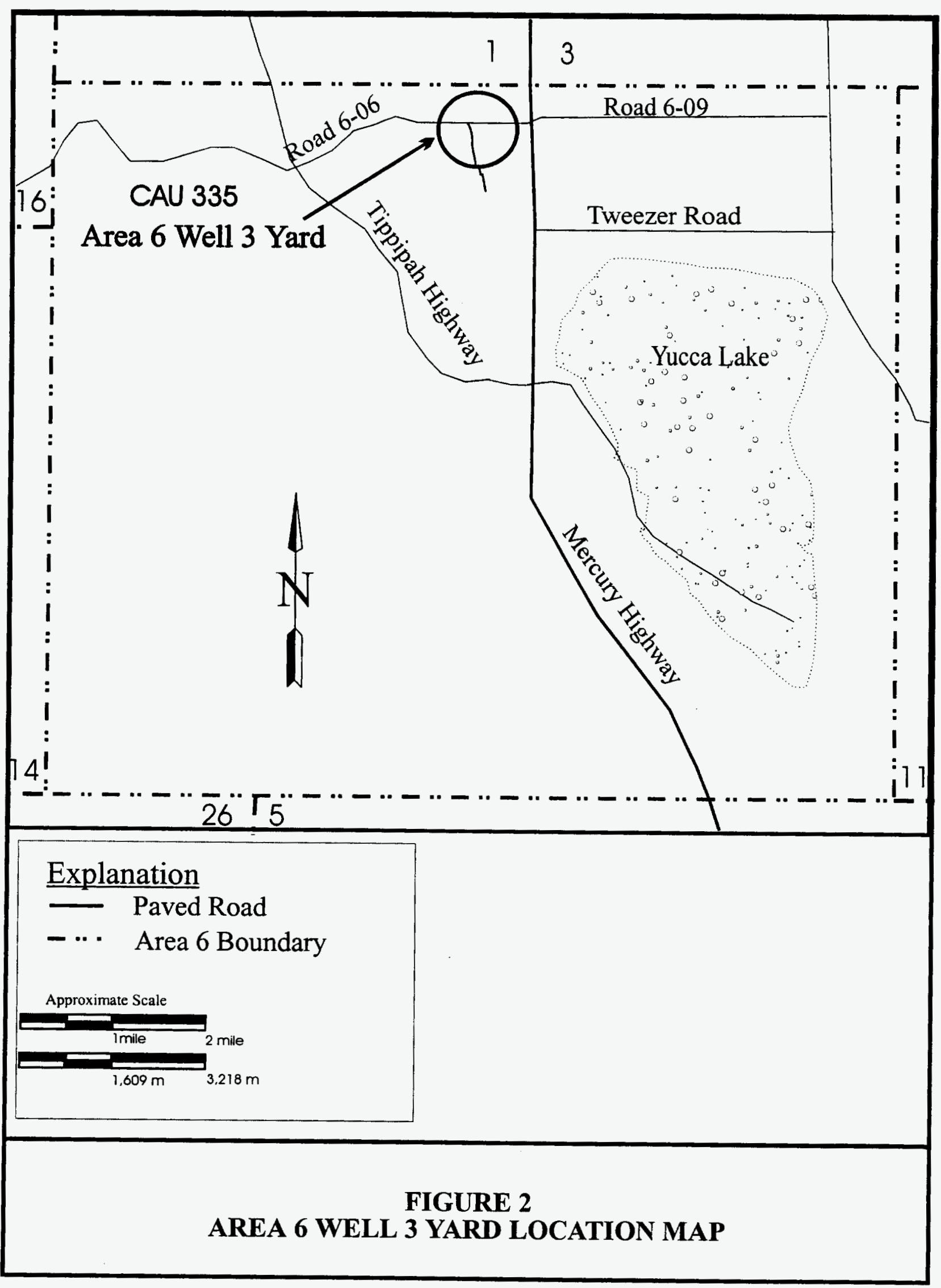




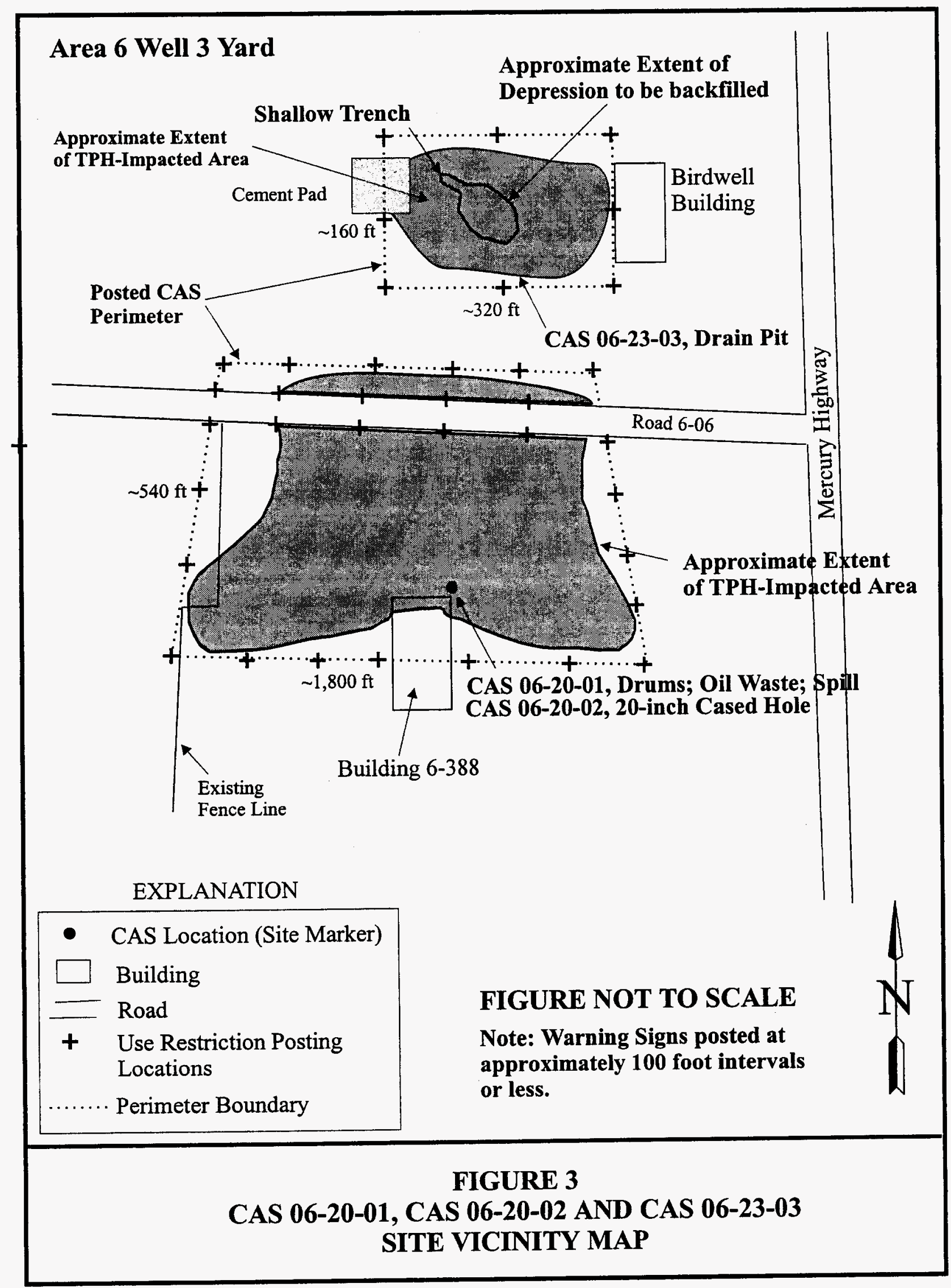




\subsection{SCOPE}

The scope of this CAP is to provide the methods for the modified implementation of the selected corrective action alternative specified in the CADD (DOE/NV, 2001). The corrective action investigation was performed in January and May of 2001. Soil sample results indicated that the only contaminant of concern (COC) detected above Preliminary Action Levels was total petroleum hydrocarbons (TPH) as diesel-range organics. The complete analytical results for the characterization samples are reported in the CADD (DOE/NV, 2001). The scope of the approved corrective action alternative consists of the following activities:

- $\quad$ No further action at CAS 06-20-01, Drums; Oil Waste; Spill; Any spills associated with CAS 06-20-01 are addressed and considered a part of CAS 06-20-02.

- CAS 06-20-02, 20-inch Cased Hole; Closed in Place with administrative controls, i.e., use restrictions and site postings which will be used to prevent intrusive activities at the site.

- CAS 06-23-03, Drain Pit; Closed in Place with administrative controls, use restrictions and site postings which will be used to prevent intrusive activities at the site. Activities will include grouting the plastic pipe protruding from the wall of the Drain Pit, backfilling the Drain Pit with clean fill, and grading to a natural slope to eliminate ponding.

\subsection{CORRECTIVE ACTION PLAN CONTENTS}

This document is divided into the following sections in accordance with the approved FFACO

CAP outline:

- Section 1.0 - Introduction

- $\quad$ Section 2.0 - Detailed Statement of Work

- Section 3.0 - Schedule

- Section 4.0 - Post-Closure Monitoring Plan

- $\quad$ Section 5.0 - References

The appendices of this document have been modified from the approved FFACO outline. The following FFACO outline appendices have not been included as indicated below:

- $\quad$ Appendix A1: Engineering Specifications and Drawings

This appendix is not included in the CAP because no engineering requirements are needed for site closure. 
- Appendix A2: Sampling and Analysis Plan

This appendix is not included in the CAP because verification sampling is not required for site closure. CAU 335 is being closed in place with administrative control.

- Appendix A3: Project Organization

This appendix is included in the CAP and is identified as Appendix A.

This plan was developed using information and guidance provided from the following documents:

- $\quad$ Federal Facility Agreement and Consent Order, (FFACO,1996).

- $\quad$ Corrective Action Investigation Plan for Corrective Action Unit 335: Area 6 Injection Well and Drain Pit, Nevada Test Site, Nevada, (DOE/NV, 2000)

- $\quad$ Corrective Action Decision Document for Corrective Action Unit 335: Area 6 Injection Well and Drain Pit, Nevada Test Site, Nevada, (DOE/NV, 2001) 


\subsection{DETAILED STATEMENT OF WORK}

\subsection{CORRECTIVE ACTIONS}

This section describes the approved corrective actions that will be implemented to close CAU 335, Area 6 Injection Well and Drain Pit. Based on the site characterization results (DOE/NV, 2001), the CADD recommends the following closure alternatives:

- $\quad$ CAS 06-20-01, Drums; Oil Waste; Spill; Closed with no further action required.

- CAS 06-20-02, 20-inch Cased Hole; Closed in Place with Administrative Controls, including use restrictions and site postings.

- CAS 06-23-03, Drain Pit; Closed in Place with Administrative Controls, including use restrictions and site postings, grouting the drain pipe protruding from the wall of the Drain Pit, backfilling the Drain Pit with clean fill, and grading to a natural slope to eliminate ponding.

Due to the large area that requires fencing, it is proposed that instead of installing a fence, posted warning signs be used to delineate the perimeter of the use restriction areas.

Closure in place with Administrative Controls, including use restrictions and site postings will be used to prevent intrusive activities at the sites. The proposed monitoring consists of annual visual inspections of the signs for two years to verify that the signs are in place and readable, and that use restrictions are maintained. Any identified maintenance and repair requirements will be reported to U.S. Department of Energy, National Nuclear Security Administration Nevada Operations Office (NNSA/NV) and NDEP and maintenance completed within 90 working days of discovery. Results of all inspections for a given year will be addressed in a single letter report submitted annually to the NDEP. If after two years, monitoring indicates that no maintenance requirements are necessary, the NNSANV may propose to the NDEP a change in the postclosure monitoring frequency.

\subsubsection{Preplanning and Site Preparation}

Prior to beginning closure activities, the following planning and preparation activities will be accomplished:

- $\quad$ Preparation of planning documents such as a Site-Specific Health and Safety Plan (SSHASP), a Field Management Plan, a National Environmental Policy Act (NEPA) Checklist, and a NNSA/NV Real Estate/Operations Permit (REOP).

- Site preparation including utility clearance as needed and work permits.

- Scheduling and coordination of the closure work. 


\subsubsection{Site-Specific Health and Safety Plan/Job Hazard Analysis}

A SSHASP and a Job Hazard Assessment (JHA) will be prepared for the site closure work. A copy of the SSHASP will be kept on file in the Bechtel Nevada (BN) Environmental Restoration Office in Mercury, Nevada. The original signature copy of the SSHASP will be kept on file at the work site and will be available for review. All personnel working at CAU 335 are required to read and sign the SSHASP prior to beginning work at the site. The SSHASP will provide a sitespecific plan to mitigate site hazards, discuss site monitoring, accident reporting, and emergency procedures. Site work will be performed following the appropriate BN Company Directives as listed in the SSHASP. In addition, Material Safety Data Sheets for all chemicals used on site will be available at the job site command post.

\subsubsection{Field Management Plan}

A Field Management Plan will be prepared for the closure activities. The plan will identify the responsible parties for each aspect of the project and determine how decisions will be made. Copies of the Field Management Plan will be placed on file at the BN Environmental Restoration office in Mercury, Nevada, at the job site.

\subsubsection{National Environmental Policy Act Documentation}

A NEPA checklist will be completed prior to beginning field work. Information from a biological survey will be used to report on the condition of existing vegetation and wildlife immediately adjacent to the area which may be affected by construction activities, equipment and material storage areas, and access routes.

\subsubsection{Closure Field Activities}

\subsubsection{CAS 06-20-01 Drums; Oil Waste; Spill Closure Activities}

CAS 06-20-0, Drums; Oil Waste; Spill, will be closed with no further action; no field activities will be performed at this site.

\subsubsection{CAS 06-20-02 20-inch Cased Hole Closure Activities}

The CADD (DOE/NV, 2001) concludes that the lateral extent of TPH impacted soil at CAS 06-20-02, 20-inch Cased Hole, is generally confined to the north by Road 6-06, to the east by the Mercury Highway, and to the west by the boundaries of the drilling supply storage area; TPH was not found south of Building 6-388 or in an approximately 36 meters (m) (120 feet [ft]) wide zone paralleling the Mercury Highway (DOE/NV, 2001) (Figure 3).

CAS 06-20-02 will be Closed in Place with Administrative Controls. This will prevent inadvertent contact with COCs. Assuming a conservative approach, the 06-20-02 area will be bounded by a rectangular perimeter extending from the south to the north across access Road 6-06. The approximate dimensions of the rectangular boundary are 548.6 by $158.5 \mathrm{~m}$ $(1,800$ by $520 \mathrm{ft})$. Site closure will be accomplished by posting warning signs along the perimeter of the CAS every $30.5 \mathrm{~m}(100 \mathrm{ft})$ to delineate the use restriction area (Figure 3$)$. In 
addition warning signs will be posted every $30.5 \mathrm{~m}(100 \mathrm{ft})$ along both the north and south sides of access Road 6-06. The warning signs will identify the site, warn against intrusive activities, and provide point of contact information. The corners of the use restriction area will be surveyed and the use restriction information entered into the Facility Information Management System.

\subsubsection{CAS 06-23-03 Drain Pit Closure Activities}

According to the CADD (DOE/NV, 2001) the lateral extent of TPH impacted soil at CAS 06-23-03, Drain Pit, is generally confined to the east by the Birdwell Building, to the west by a large concrete pad, and to the south by Road 6-06 (Figure 3).

CAS 06-23-03 will be Closed in Place with Administrative Controls. Assuming a conservative approach, the 06-23-03 area will be bounded by a rectangular perimeter measuring approximately 97.5 by $36.5 \mathrm{~m}$ ( 320 by $160 \mathrm{ft}$ ). Site closure will be accomplished by posting warning signs along the perimeter of the CAS every $30.5 \mathrm{~m}(100 \mathrm{ft})$ to delineate the use restriction area (Figure 3). The warning signs will identify the site, warn against intrusive activities, and provide point of contact information. The corners of the use restriction area will be surveyed and the use restriction information entered into the Facility Information Management System. In addition to posting warning signs, the plastic drainpipe protruding from the northwest wall of the Drain Pit will be grouted closed. The Drain Pit will then be backfilled with clean fill and graded to a natural slope to prevent ponding. The Drain Pit is oblong shaped and measures approximately $19.5 \mathrm{~m}(65 \mathrm{ft})$ by $11 \mathrm{~m}(37 \mathrm{ft})$ and is $1.2 \mathrm{~m}(4 \mathrm{ft})$ to $1.8 \mathrm{~m}(6 \mathrm{ft})$ deep. A shallow ditch measuring $5 \mathrm{~m}(17 \mathrm{ft})$ long that empties into the northwest edge of the pit will also be backfilled with clean fill and graded to a natural slope.

\subsubsection{Best Management Practices}

As a best management practice loose debris, sanitary waste, and weeds that obscure the visibility of site postings will be collected from the two posted CASs and disposed of appropriately.

\subsection{CONSTRUCTION QUALITY ASSURANCE/QUALITY CONTROL}

Due to the nature of the closure activities construction quality assurance/quality control requirements are not required.

\subsection{WASTE MANAGEMENT}

CAU 335 closure activities will generate sanitary waste only, including uncontaminated personal protective equipment (PPE) and trash generated by personnel on the site. Sanitary waste will be containerized and disposed of appropriately. Drums used at the site for waste storage/disposal will be appropriately labeled. Site personnel will follow the principles of the BN Waste Minimization and Pollution Prevention Program. 


\subsubsection{Waste Minimization}

For the duration of the project, site workers will adhere to the BN Waste Minimization and Pollution Prevention Program. Care will be taken to segregate waste from non-waste materials, when possible, to avoid the generation of additional regulated waste.

\subsubsection{Site Control}

Where appropriate, temporary barricades (fencing, rope, warning cones, etc.) will be placed around the work zones. Appropriate warning signs will be posted. Only properly trained personnel, wearing appropriate PPE, as specified in the SSHASP will be allowed to enter the work zones. Site layout maps are contained within the SSHASP.

\subsubsection{Personnel Training}

All personnel will be required to read, understand, and sign the SSHASP prior to working at the site. A daily safety briefing will be held every morning prior to beginning work and, as needed, as activities or circumstances change. Only trained and qualified personnel will operate equipment. Training requirements will be specified in the SSHASP.

\subsection{CONFIRMATION OF CORRECTIVE ACTIONS}

A field logbook will be maintained during the closure in place. The activities will be recorded in a bound logbook with numbered pages and will include the following information:

- Dates and times of events

- Names of persons at the site

Field notes will be recorded in black ink. Any errors will be crossed out with a single line and initialed. In addition, photographs of all closure activities will be collected. Field notes, site photographs and daily reports will be the basis for the closure report.

\subsubsection{Verification Sampling}

Verification sampling is not required for site closure. CAU 335 will be closed in place with administrative control and use restrictions to prevent intrusive activities at CAS 06-20-02 and CAS 06-23-03.

\subsection{PERMITS}

Permits required for this project include an Excavating and Penetration permit and a REOP and the REOP subpart B NTS Operations Schedule. These permits will be obtained prior to the start of field activities. 


\subsubsection{Excavating and Penetration Permit}

An approved Excavating and Penetration Permit (BN form number BN-0084) will be obtained prior to the start of field work. The permit contains a justification for the penetration operation and a checklist of pertinent organizations which must inspect the site so that activities will not impact utilities or cause a hazardous situation to workers. A copy of this permit will be kept on file at the job site by the construction superintendent.

\subsubsection{Real Estate/Operations Permit}

A NNSA/NV REOP permit will be completed and approved prior to starting field activities. This permit authorizes BN the right of occupancy and use of the NNSA/NV real estate for closure activities. A REOP Subpart B, NTS Operation Schedule, will be submitted to NTS Site Operation Center prior to starting work and will be updated as required. 
CAP - CAU 335

Section: Statement of Work

Revision: 1

Date: October 2002

THIS PAGE INTENTIONALLY LEFT BLANK 


\subsection{SCHEDULE}

The schedule will require modification if conditions exist that are outside the assumptions on which the schedule was developed. The NNSA/NV will keep the NDEP appraised of any conditions that may impact the project schedule. In the event that the project schedule requires modifications, the NNSANNV will consult with NDEP personnel prior to making any changes.

A tentative schedule for planned work consists of the following:

- $\quad$ Pre-field Activities

Fall 2002

- $\quad$ Field Closure Activities

January - April 2003

- $\quad$ Final Closure Report
August 29, 2003

Field work will be done in the safest and most efficient manner possible. Sufficient flexibility has been placed in the project schedule to account for minor difficulties (weather, equipment breakdown, etc.). 
CAP - CAU 335

Section: Schedule

Revision: 1

Date: October 2002

THIS PAGE INTENTIONALLY LEFT BLANK 


\subsection{POST-CLOSURE MONITORING PLAN}

The proposed monitoring consists of annual (yearly) visual inspections of the postings for two years to verify that the postings are in place, readable and that use restrictions are maintained. Any identified maintenance and repair requirements will be reported to NDEP and completed within 90 working days of discovery. Results of all inspections for a given year will be addressed in a single letter report submitted annually to the NDEP. If after two years, monitoring indicates that no maintenance requirements are necessary, the NNSA/NV may propose to the NDEP a change in the post-closure monitoring frequency.

\subsection{INSPECTIONS}

Inspections consist of annual (yearly) visual inspections of the postings for two years to verify that the postings are in place, readable and that use restrictions are maintained. Any identified maintenance and repair requirements will be reported to NDEP and completed within 90 working days of discovery.

\subsection{REPORTING}

Results of all inspections in a given year will be addressed in a single annual letter report. The annual report will include the following information:

- Discussion of observations and inspections

- $\quad$ Copies of the site Inspection Checklists

- $\quad$ Site photographs

- $\quad$ Copies of the field notes

- Any maintenance records

\subsection{MAINTENANCE AND REPAIR}

Any identified maintenance and repair requirements will be reported to NDEP and completed within 90 working days of discovery. Results of all inspections for a given year will be addressed in a single letter report submitted annually to the NDEP. If after two years, monitoring indicates that no maintenance requirements are necessary, the NNSA/NV may propose to the NDEP a change in the post-closure monitoring frequency.

\subsection{LAND USE RESTRICTIONS}

The future use of any land related to CAU 335 is restricted from any activity that may alter or modify the containment control as approved by the NDEP and identified in the CAU 335 Closure Report unless appropriate concurrence is obtained in advance. 
The CAU Land Use Restriction form will be completed and included in the Closure Report. This form includes the CAU number and site description, post-closure monitoring requirements, and survey coordinates of the unit boundaries. The information on the completed form will be added to the NNSA/NV Facility Information Management System and the Central Data Repository. The original CAU Land Use Restriction form is then filed within the CAU 335 project file. 


\subsection{REFERENCES}

DOE/NV, see U.S. Department of Energy, Nevada Operations Office.

Federal Facility Agreement and Consent Order, 1996 (as amended). Agreed to by the State of Nevada, U.S. Department of Energy, and U.S. Department of Defense.

FFACO, see Federal Facility Agreement and Consent Order.

NAC, see Nevada Administrative Code.

Nevada Administrative Code, 1996. NAC 445A.2272, "Contamination of soil: Establishment of action levels," as adopted by the Nevada Environmental Commission, September, Carson City, NV.

U.S. Department of Energy, Nevada Operations Office, 2000. Corrective Action Investigation Plan for Corrective Action Unit 335: Area 6 Injection Well and Drain Pit, Nevada Test Site, Nevada, Revision 0, DOE/NV-663, Las Vegas, NV.

U.S. Department of Energy, Nevada Operations Office, 2001. Corrective Action Decision Document for Corrective Action Unit 335: Area 6 Injection Well and Drain Pit, Nevada Test Site, Nevada, Revision 0, DOE/NV-759, Las Vegas, NV. 
CAP - CAU 335

Section: References

Revision: 1

Date: October 2002

THIS PAGE INTENTIONALLY LEFT BLANK 
Date: October 2002

\section{APPENDIX A-1}

\section{ENGINEERING SPECIFICATION AND DRAWINGS}


CAP - CAU 335

Section: Appendix A-1

Revision: 1

Date: October 2002

\section{THIS PAGE INTENTIONALLY LEFT BLANK}


Appendix A-1 of the Standardized Outline for a FFACO Corrective Action Plan, Engineering Specification and Drawing, is not applicable to the closure of CAU 335. The site will be closed by posting and implementing land use restrictions. No engineering specifications or drawings are required or necessary for closure of CAU 335. 
CAP - CAU 335

Section: Appendix A-1

Revision: 1

Date: October 2002

THIS PAGE INTENTIONALLY LEFT BLANK 


\section{APPENDIX A-2}

\section{SAMPLING AND ANALYSIS PLAN}


CAP - CAU 335

Section: Appendix A-2

Revision: 1

Date: October 2002

THIS PAGE INTENTIONALLY LEFT BLANK 
Appendix A-2 of the Standardized Outline for a FFACO Corrective Action Plan, Sampling and Analysis Plan, is not applicable to the closure of CAU 335. The site will be closed by posting and implementing land use restrictions. No samples will be collected for CAU 335 site closure verification. 
CAP - CAU 335

Section: Appendix A-2

Revision: 1

Date: October 2002

THIS PAGE INTENTIONALLY LEFT BLANK 


\section{APPENDIX A-3}

\section{PROJECT ORGANIZATION}


Section: Appendix A-3

Revision: 1

Date: October 2002

THIS PAGE INTENTIONALLY LEFT BLANK 


\section{PROJECT ORGANIZATION}

The U.S. Department of Energy, National Nuclear Security Administration Nevada Office (NNSA/NV) Project Manager or Task Manager will serve as the primary point of contact for all activities conducted for this project. The NNSA/NV Project Manager will be the primary point of contact with the Nevada Division of Environmental Protection. The NNSA/NV points of contact for this project are as follows:

Project Manager: Janet Appenzeller-Wing

Telephone Number: (702) 295-0461

Task Manager: Sabine Curtis

Telephone Number: (702) 295-0542

The Bechtel Nevada (BN) Environmental Restoration personnel and the reporting structure can be found in the Field Management Plan and the Site-Specific Health and Safety Plan (SSHASP), however personnel are subject to change. Contact the BN Environmental Restoration Task Manager for current project and personnel information. Requirements for personnel training will be provided in the SSHASP. 
CAP - CAU 335

Section: Appendix A-3

Revision: 1

Date: October 2002

THIS PAGE INTENTIONALLY LEFT BLANK 


\section{APPENDIX A-4}

\section{NEVADA DIVISION OF ENVIRONMENTAL PROTECTION COMMENT RESPONSE}


Section: Appendix A-4

Revision: 1

Date: October 2002

THIS PAGE INTENTIONALLY LEFT BLANK 


\section{NEVADA ENVIRONMENTAL RESTORATION PROJECT DOCUMENT REVIEW SHEET}

\begin{tabular}{|c|c|c|c|c|}
\hline \multirow{4}{*}{\multicolumn{3}{|c|}{$\begin{array}{l}\text { 1. Document Title/Number: Final Corrective Action Plan for Corrective } \\
\text { Action Unit 335:Area } 6 \text { Injection Well and Drain Pit Nevada Test Site, } \\
\text { Nevada } \\
\text { 3. Revision Number: } \underline{0} \\
\text { 5. Responsible NNSA/NV ERP Project Mgr.: Janet Appenzeller-Wing } \\
\text { 7. Review Criteria: Federal Facility Agreement and Consent Order } \\
\text { 8. Reviewer/Organization/Phone No.: Greg Raab, Matthew DeBurle / } \\
\underline{\text { Nevada Division of Environmental Protection / 702-486-2867, 702-678- }} \\
\underline{4670}\end{array}$}} & \multicolumn{2}{|l|}{ 2. Document Date: June 2002} \\
\hline & & & \multicolumn{2}{|l|}{ 4. Originator/Organization: Bechtel Nevada } \\
\hline & & & \multicolumn{2}{|l|}{ 6. Date Comments Due: September 302002} \\
\hline & & & \multicolumn{2}{|l|}{ 9. Reviewer's Signature } \\
\hline $\begin{array}{c}10 . \\
\text { Comment } \\
\text { Number/ } \\
\text { Location } \\
\end{array}$ & $\begin{array}{l}11 . \\
\text { Type }^{\mathrm{a}}\end{array}$ & $\begin{array}{c}12 . \\
\text { Comment }\end{array}$ & $\begin{array}{c}13 . \\
\text { Comment Response }\end{array}$ & $\begin{array}{c}14 . \\
\text { Accept } \\
Y / N\end{array}$ \\
\hline $\begin{array}{l}\text { 1. Table of } \\
\text { Contents } \\
\text { and } \\
\text { Appendices }\end{array}$ & M & $\begin{array}{l}\text { In the draft CAP which NDEP reviewed, under listing } \\
\text { "Appendices" in the Table of Contents, and in the Appendix } \\
\text { Section, Appendices A-1 and A-2 are missing. Appendix A-1, } \\
\text { Engineering Specifications and Drawings, is the appropriate } \\
\text { location to show a typical warning sign, how it is to be installed, } \\
\text { and the exact locations of each sign on a scale drawing of the site(s). }\end{array}$ & $\begin{array}{l}\text { Placeholders for Appendices A-1 and A-2 have been } \\
\text { included in the CAP. In addition, an "as-built" } \\
\text { drawing showing the method of installation and the } \\
\text { location for all installed warning signs will be } \\
\text { provided in the CAU } 335 \text { Closure Report (CR). See } \\
\text { also comment/response number } 3 \text {. }\end{array}$ & Yes \\
\hline $\begin{array}{l}2 . \\
\text { Appendix } \\
\text { A-2 }\end{array}$ & $M$ & $\begin{array}{l}\text { Appendix A-2, Sampling and Analysis Plan, may not be applicable } \\
\text { to this particular site, but a place holder Appendix should be } \\
\text { included, which states that this section is not applicable. }\end{array}$ & We will include a placeholder for Appendix A-2. & Yes \\
\hline
\end{tabular}




\begin{tabular}{|c|c|c|c|c|}
\hline $\begin{array}{l}10 . \\
\text { Comment } \\
\text { Number/ } \\
\text { Location }\end{array}$ & $\begin{array}{l}11 \\
\text { Type }^{\mathrm{a}}\end{array}$ & $\begin{array}{c}12 . \\
\text { Comment }\end{array}$ & $\begin{array}{c}13 . \\
\text { Comment Response }\end{array}$ & $\begin{array}{l}14 . \\
\text { Accept } \\
\text { Y/N }\end{array}$ \\
\hline $\begin{array}{l}\text { 3. Section } \\
2.1 .2 .2 ., \\
2.1 .2 .3 \text { and } \\
\text { Figure } 3 \text {. }\end{array}$ & $\mathrm{M}$ & $\begin{array}{l}\text { In the review of the draft CAP, NDEP directed NNSA/NV to define } \\
\text { the number of signs and identify the locations for installation. } \\
\text { NDEP also directed NNSA/NV to justify why this option was not } \\
\text { presented in the CADD, since NNSA/NV would have already } \\
\text { known the aerial extent of the site. NNSA/NV addressed this } \\
\text { comment satisfactorily in Appendix B, however the detailed } \\
\text { information (i.e. exact number of signs and locations) was not } \\
\text { added to the discussion in sections } 2.1 .2 .2 \text { and } 2.1 .2 .3 \text {. } \\
\text { Additionally, Figure } 3 \text { does not have any signs posted along the } \\
\text { roadway which cuts through the contaminated site. Signs need to be } \\
\text { posted along the roadway to ensure that no vehicular traffic wanders } \\
\text { off the road in the contaminated area. }\end{array}$ & $\begin{array}{l}\text { Based upon the information presented in the CADD, a } \\
\text { conservative approach to posting CAS } 06-20-02 \text { will } \\
\text { be implemented by establishing a rectangular } \\
\text { boundary about the TPH impacted area. In addition, } \\
\text { warning signs will be posted every } 100 \mathrm{ft} \text {. on both the } \\
\text { north and south sides of the Area } 6 \text { Well } 3 \text { Yard access } \\
\text { road to warn against inadvertent entry into a closed } \\
\text { controlled CAS. } \\
\text { The text of Section } 2.1 .2 .2 \text { and } 2.1 .2 .3 \text {, and Figure } 3 \\
\text { has been changed to detail the area and frequency of } \\
\text { posting. }\end{array}$ & Yes \\
\hline $\begin{array}{l}4 . \\
\text { Appendices }\end{array}$ & $\mathrm{M}$ & $\begin{array}{l}\text { The Appendices in the document were not in sequential order. All } \\
\text { Appendices need to be in sequential order. }\end{array}$ & $\begin{array}{l}\text { The Appendices have been placed in sequential order } \\
\text { throughout the document (i.e. Table of Contents and } \\
\text { Appendices section). }\end{array}$ & Yes \\
\hline
\end{tabular}

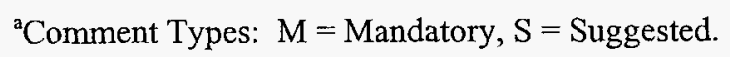


CAP - CAU 335

Section: Distribution

Revision: I

Date: October 2002

\section{DISTRIBUTION LIST}


CAP - CAU 335

Section: Distribution

Revision: 1

Date: October 2002

THIS PAGE INTENTIONALLY LEFT BLANK 


\section{DISTRIBUTION LIST}

*Provide copy of initial distribution of all revisions; others receive NDEP-approved revision only.

\section{Nevada Division of Environmental Protection}

Paul Liebendorfer

1 (Controlled)* $^{*}$

Bureau of Federal Facilities

Division of Environmental Protection

333 W. Nye Lane, Room 138

Carson City, NV 89706-0866

Don Elle

1 (Controlled)* $^{*}$

Bureau of Federal Facilities

Division of Environmental Protection

1771 E. Flamingo, Suite 121-A

Las Vegas, NV 89119-0837

\section{U.S. Department of Energy}

Janet Appenzeller-Wing

1 (Uncontrolled)*

Project Manager

Environmental Restoration Division

U.S. Department of Energy

National Nuclear Security Administration

Nevada Operations Office

P.O. Box $98518 \mathrm{M} / \mathrm{S} 505$

Las Vegas, NV 89193-8518

Sabine Curtis

1 (Uncontrolled)*

Environmental Restoration Division

U.S. Department of Energy

National Nuclear Security Administration

Nevada Operations Office

P.O. Box $98518 \mathrm{M} / \mathrm{S} 505$

Las Vegas, NV 89193-8518

Sabrina Lawrence

Environmental Restoration Division

1 (Controlled)*

U.S. Department of Energy

National Nuclear Security Administration

Nevada Operations Office

P.O. Box $98518 \mathrm{M} / \mathrm{S} 505$

Las Vegas, NV 89193-8518 


\section{DISTRIBUTION LIST (continued)}

\section{U.S. Department of Energy (continued)}

U.S. Department of Energy

National Nuclear Security Administration

2 (1 Controlled \&

Nevada Operations Office

1 Uncontrolled)

Public Reading Facility

P.O. Box $98521 \mathrm{M} / \mathrm{S}$ NLV040

Las Vegas, NV 89193-8521

U.S. Department of Energy

1 (Uncontrolled)

National Nuclear Security Administration

Nevada Operations Office

Technical Information Resource Center

P.O. Box $98521 \mathrm{M} / \mathrm{S} 505$

Las Vegas, NV 89193-8521

U.S. Department of Energy

Office of Scientific and Technical Information

1 (Electronic copy)

P.O. Box 62

Oak Ridge, TN 37831-0062

\section{Bechtel Nevada}

Correspondence Control

1 (Uncontrolled)*

Bechtel Nevada

P.O. Box 98521 M/S NLV008

Las Vegas, NV 89193-8521

Environmental Management Library

1 (Uncontrolled)*

Bechtel Nevada

P.O. Box 98521 N/S NLV080

Las Vegas, NV 89193-8521

Ann Heidema

1 (Uncontrolled)

Bechtel Nevada

P.O. Box $98521 \mathrm{M} / \mathrm{S}$ NLV022

Las Vegas, NV 89193-8521

Wayne Johnson

1 (Uncontrolled)*

Bechtel Nevada

P.O. Box $98521 \mathrm{M} / \mathrm{S}$ NLV080

Las Vegas, NV 89193-8521 


\section{DISTRIBUTION LIST (continued)}

\section{Bechtel Nevada (continued)}

Daniel Kirker

Bechtel Nevada

1 (Uncontrolled)*

P.O. Box $98521 \mathrm{M} / \mathrm{S}$ NTS306

Las Vegas, NV 89193-8521

Steve Nacht

1 (Uncontrolled)*

Bechtel Nevada

P.O. Box $98521 \mathrm{M} / \mathrm{S}$ NTS306

Las Vegas, NV 89193-8521

Glen Richardson

Bechtel Nevada

P.O. Box $98521 \mathrm{M} / \mathrm{S}$ NTS306

Las Vegas, NV 89193-8521

\section{IT Corporation}

IT FFACO Support Office

1 (Controlled)

IT Corporation

P.O. Box $93838 \mathrm{M} / \mathrm{S} 439$

Las Vegas, NV 89193-8521

Lynn Kidman

1 (Uncontrolled)*

IT Corporation

P.O. Box 93838 M/S 439

Las Vegas, NV 89193-8521

\section{State of Nevada}

Manager, Northern Nevada

FFACO Public Reading Facility

1 (Uncontrolled)*

Nevada State Library and Archives Federal Publications

100 North Stewart Street

Carson City, NV 89701-4285 
CAP - CAU 335

Section: Distribution

Revision: 1

Date: October 2002

THIS PAGE INTENTIONALLY LEFT BLANK 